Alicja Andrzejewska-Zając

(Muzeum Narodowe w Gdańsku)

https://orcid.org/0000-0003-2689-1772

\title{
Dwa capriccia architektoniczne z kolekcji Muzeum Narodowego w Gdańsku - próba atrybucji
}

DOI: https://doi.org/10.26881/porta.2019.18.05

Malarstwo włoskie w zbiorach Muzeum Narodowego w Gdańsku nie należy do głównego profilu kolekcji, stanowiąc w dużej mierze przypadkowy zespół powojennych przekazów i pojedynczych nabytków. Dzięki wystawie „Włochy w Gdańsku", która odbyła się na przełomie 2018 i 2019 r., zaprezentowano wiele włoskich dzieł z muzealnego zbioru, które nie były dotąd przedmiotem badań naukowych i w większości eksponowano je po raz pierwszy. Dwa z nich, o nieznanej bliżej proweniencji, namalowane przez anonimowych twórców, przedstawiające malownicze capriccia architektoniczne, wyróżniają się na tle muzealnej kolekcji malarstwa obcego, prezentując wysoką klasę artystyczną. W niniejszym artykule podjęty zostanie problem ich tematyki i atrybucji.

W kontekście rozważań nad tematem obu obrazów, należy przywołać rolę i znaczenie capriccia jako kategorii artystycznej o szerokim zasięgu i znacznych trudnościach badawczych. Występujące w różnych kontekstach, niejednorodne pod względem tematycznym i przedstawieniowym, przynależne wielu dziedzinom, jest ono trudne do sklasyfikowania i zdefiniowania ${ }^{1}$. W odniesieniu do sztuk pięknych określa wszystko to, co wymyka się regułom opracowanym przez Leona Battistę Albertiego, wedle których malarstwo - choć nazwane przezeń finestra aperta - podlega stałym i obiektywnym wzorcom ${ }^{2}$. Korzystając z licznych przykładów, Ekkehard Mai we wstępie do katalogu wystawy Das Capriccio als Kunstprinzip opisuje to zjawisko jako artystyczną innowacyjność, fantazję, spontaniczność i indywidualne poszukiwania w zakresie form, treści czy funkcji, przy jednoczesnej świadomości konwencji i reguł³.

1 Pierwszą próbę przeanalizowania terminu capriccio jako koncepcji teoretyczno-artystycznej występującej we wszystkich dziedzinach sztuki podjął Enrico Crispolti, Enciclopedia Universale dell 'Arte, Venezia-Roma 1958, s. 103-110. Zob. też Lucrezia Hartmann, Capriccio. Bild und Begriff, Nürnberg 1973; Das Capriccio als Kunstprinzip. Zur Vorgeschichte der Moderne von Arcimboldo und Callot bis Tiepolo und Goya. Malerei - Zeichnung - Graphik, red. Ekkehard Mai, Joachim Rees [katalog wystawy], Kunsthistorisches Museum Wien, Wien 1996; Roland Kanz, Die Kunst des Capriccio. Kreativer Eigensinn in Renaissance und Barock, München 2002.

2 Werner Hofmann, Das Capriccio als Kunstprinzip [w:] Das Capriccio als Kunstprinzip..., s. 23.

3 Ekkehard Mai, Phantasie, Invention, Capriccio - kunsttheoretische Splitter und Randbemerkungen zu einem großen Thema [w:] Das Capriccio als Kunstprinzip..., s. 16. 
Włoskie słowo capriccio (hiszp. capricho, franc. caprice) nie ma jednoznacznego pochodzenia. Jedna z koncepcji głosi, że składa się ono z dwóch włoskich wyrazów - capo (głowa) i riccio (kędzierzawy), oznaczając kędzierzawe włosy bądź „myśli unoszące włosy”. Słowo to, w takim właśnie znaczeniu, pojawia się w komentarzach Boskiej komedii Dantego Alighieri ${ }^{4}$. Inna teza, rozpowszechniona na początku XVI w., wywodzi pojęcie capriccio od łacińskiego i włoskiego zarazem słowa capra (koza), podkreślając moment nieprzewidywalności, niezwykłość pomysłów, które mogą pojawić się z nieoczekiwaną nagłością niczym skoki kozła 5 . Zanim termin capriccio stał się kategorią estetyczną w teorii sztuki, znalazł swoje miejsce w szesnastowiecznej burlesce włoskiej jako metafora idei niekonsekwentnych. W poezji Francesca Berni (capriccio bernesco) oznaczał intuicyjny, dowcipny przeskok myślowy i był najważniejszym środkiem artystycznym w jego twórczości ${ }^{6}$.

Capriccio jako określenie związane ze sztukami wizualnymi pojawia się po raz pierwszy w obu edycjach $(1550,1568)$ słynnego dzieła Le vite dei più eccelenti pittori, scultori ed architettori Giorgia Vasariego ${ }^{7}$. Tym szeroko rozumianym terminem teoretyk określa pewne stany umysłu, cechy artystów, a także tworzone przez nich niezwykłe i nowatorskie obrazy. W ewolucyjnej optyce dzieła Vasariego capriccio zajmuje znaczące miejsce, implikuje bowiem ideę badań i odnowy. Twórcze łamanie zasad w połączeniu $\mathrm{z}$ warunkiem koniecznym, jakim pozostają racjonalny osąd i znajomość zasad, inspiruje do nowych artystycznych wyzwań i rozwija sztukę. Aby dzieło mogło być uznane za godne tego terminu, musi być nowatorskie (maniera moderna), pomysłowe, wyraziste i bogato zdobione ${ }^{8}$. Alegoryczną wizualizację kaprysu można znaleźć w Ikonologii Cesarego Ripy, który sytuując go obok wielu innych przedstawień uczuć - Trwogi, Gniewu, Zdumienia, ukazuje go jako młodzieńca w kapelusiku ozdobionym piórami, podkreślając przede wszystkim niestałość i fantazję tego stanu umysłu?

Na początku XVII w. rodzi się capriccio architektoniczne - niezależny gatunek malarski ${ }^{10}$. Jest to typ pejzażu architektonicznego, w którym przedstawione budowle lub ich fragmenty, uzupełnione sztafażem, występują w fantazyjnym zestawieniu z obiektami będącymi wytworem artystycznej imaginacji malarza. Kluczowym motywem tych dzieł stają się często ruiny z elementami typowymi dla antyczno-renesansowej budowli, takimi jak kolumnady, tarasy, galerie, portyki czy arkady. Gatunek ten, rozpowszechniony w XVII stuleciu dzięki twórczości Alessandra Salucciego i Viviana Codazziego, wykorzystuje ramy

4 Kanz, Die Kunst des Capriccio..., s. 31.

Hartmann, Capriccio..., s. 7-11

Kanz, Die Kunst des Capriccio..., s. 44-50.

$\mathrm{Na}$ ten temat zob. Alice Rathé, Le capriccio dans les écrits de Vasari, „Italica. Journal of the American Association of Teachers of Italian" 1980, t. 57, nr 4, s. 239-254.

8 Kanz, Die Kunst des Capriccio..., s. 17-30; Mai, Phantasie, Invention, Capriccio..., s. 35-53.

9 Cesare Ripa, Ikonologia, przeł. Ireneusz Kania, Kraków 2004, s. 83.

10 Na temat początków capriccia architektonicznego w malarstwie zob. David Ryley Marshall, Viviano and Niccolo Codazzi and the Baroque Architectural Fantasy, Milano 1993, s. 22-24. 
Alicja konwencji pejzażowej do zobrazowania za pomocą realnych form nierealnej Andrzejewska- wizji artysty. W przeciwieństwie do rozpowszechnionej w XVIII w. weduty, -Zając której twórcy kładli nacisk na realistyczne odtworzenie topografii miasta, czy weduty idealnej obrazującej rzeczywisty widok uzupełniany budowlami z innych miejsc bądź nieistniejącymi ${ }^{11}$, capriccio architektoniczne jest $\mathrm{w}$ całości podporządkowane wyobraźni i inwencji twórcy, a jego istotą, zgodnie z założeniami Vasariego, są nowatorstwo i pomysłowość, natomiast celem - zaskoczenie widza.

Przedstawienia architektoniczne należy wywodzić - podobnie jak obrazy batalistyczne mające swoje źródło w historycznym, renesansowym malarstwie monumentalnym - z malarstwa kwadraturowego, którego elementy kompozycyjne i technikę wykreślania perspektywy zaadaptowano do malarstwa sztalugowego ${ }^{12}$. Pojawienie się w pierwszych dekadach XVII w. takich gatunków malarskich, jak pejzaże, capriccia architektoniczne, martwe natury czy obrazy batalistyczne (uchodzących za mniej istotne i niegodne wielkiej sztuki), a następnie wzrost ich popularności łączy się z narodzinami i rosnącą rolą otwartego rynku sztuki, który pozwalał artystom tworzyć dzieła poza wąskim kręgiem największych i najmożniejszych mecenasów ${ }^{13}$. Dzieła przedstawiające widoki architektoniczne lub stanowiące fantazyjne capriccia architektoniczne, które były studiami powtarzalnych motywów, tylko okazjonalnie i przez nielicznych twórców modyfikowanymi i ożywianymi nowymi detalami, pełniły funkcję dekoracyjną i szybko stały się popularnym elementem wystroju siedemnastowiecznych wnętrz. Podporządkowane perspektywicznym zasadom, z czytelnymi akcentami wertykalnymi i horyzontalnymi, wprowadzały różnorodność i optycznie porządkowały ścienną dekorację ${ }^{14}$. Dzieła te cieszyły się także dużą popularnością wśród zagranicznych koneserów i miłośników sztuki podróżujących do Italii, którzy poszukiwali do swych kolekcji malowanych, rytowanych lub rysunkowych widoków odwiedzanych miejsc - innymi słowy, przedstawień znanych włoskich budowli czy malowniczych ruin, postrzeganych jako źródło tradycji europejskiej.

Fascynacja ruinami, będąca wyrazem nostalgii za utraconym światem antyku rzymskiego, objawiła się już w XVI w. w twórczości północnych manierystów działających w Rzymie: Étienne Dupéraca, Maartena van Heemskerck czy Hiëronymusa Cocka ${ }^{15}$. Dla nich Italia była najpełniejszą realizacją ideału locus

11 Marshall, Viviano and Niccolò Codazzi..., s. 23.

12 Federico Zeri, La nascità della „Battaglia come genere” e il ruolo del Cavalier d’Arpino [w:] La battaglia nella pittura del XVII e XVIII secolo, red. Patrizia Consigli Valenti, Parma 1986, s. 9-27.

13 Patrizia Cavazzini, Painting as Business in Early Seventeenth-Century Rome, Pennsylvania 2008, s. 1.

14 David Ryley Marshall, The Roman Baths Theme from Viviano Codazzi to G. P. Pannini: transmission and transformation, „Artibus et Historiae” 1991, t. 12, nr 23, s. 129.

15 Zespół 172 rysunków Maartena van Heemskerck powstał podczas pobytu artysty w Rzymie (1532-1536); przechowywany jest do dziś w zbiorach graficznych w Berlinie, zob. Christian Hülsen, Hermann Egger, Die Römischen Skizzenbücher von Maarten van Heemskerck im Königlichen 
amoenus $^{16}$, zaś słowa Francesca Albertiniego: Roma quanta fuit ipsa ruina docet, umieszczone przez van Heemskercka na rysunku przedstawiającym rzymskie Septizonium, świadczą o fascynacji reliktami minionej potęgi rzymskiej kultury ${ }^{17}$. W praktyce owo zainteresowanie objawiało się studiowaniem pozostałości architektury klasycznej oraz odtwarzaniem jej z natury, z wielką precyzją i dbałością o detal. Architektura starożytna, utrwalana w rysunkach i szkicach, była $\mathrm{z}$ kolei wykorzystywana jako tło dla mitologicznych kompozycji malarskich i materiał przygotowawczy dla graficznych serii wydawanych od połowy XVI w.

Pierwszym zestawem rycin ukazującym rzymskie ruiny, który stanowił inspirację dla innych twórców i miał ogromny wpływ na postrzeganie Wiecznego Miasta, był cykl autorstwa Cocka Praecipua aliquot Romanae antiquitatis ruinarum monimenta [...] designata, wydany w 1551 r., a w późniejszych latach wznawiany i kopiowany (m.in. w 1582 r. przez Battistę Pittoniego jako ilustracje przewodnika Vincenza Scamozziego Discorso sopra le antichità di Roma) ${ }^{18}$. Ryciny te, ukazujące rozkład, który jest rezultatem upływającego czasu, już na początku XVII stulecia przestały mieć znaczenie jako dokumenty antykwaryczne, stając się źródłem motywów ikonograficznych dla przedstawień nieistniejącego Rzymu, aranżowanych w dowolny sposób przez artystów. W tym kontekście powstają też pierwsze capriccia architektoniczne, już nie tylko jako tło obrazów historycznych bądź mitologicznych, lecz także jako pełnoprawny temat, wart artystycznej uwagi. Mimo że duża liczba tych dzieł zachowała się w kolekcjach i na współczesnym rynku antykwarycznym, to pozostają one jednym z najtrudniejszych do badania gatunków malarskich. Wynika to głównie $\mathrm{z}$ faktu, że capriccia nie były zwykle wykonywane przez artystów najwyższej klasy, wiele obrazów pozostaje anonimowych, a ich znaczne rozproszenie sprawia, że niełatwo jest zrekonstruować kariery twórców specjalizujących się w tego typu kompozycjach.

Pierwszy z dwóch omawianych tu gdańskich obrazów ${ }^{19}$ (il. 1), namalowany techniką olejną na płótnie, w kolekcji gdańskiego muzeum znalazł się

Kupferstichkabinett zu Berlin, Bd. 1-2, Berlin 1913-1916 [za: Arthur J. DiFuria, Maarten van Heemskerck's Rome. Antiquity, Memory, and the Cult of Ruins, Leiden-Boston 2018, s. 6].

16 Jan Białostocki, Narodziny nowożytnego krajobrazu [w:] Narodziny krajobrazu nowożytnego. Katalog wystawy ze zbiorów Ermitażu, Drezna, Pragi, Budapesztu oraz muzeów polskich [katalog wystawy], Muzeum Narodowe w Warszawie, Warszawa 1972, s. 15.

17 Francesco Albertini, Opusculum de mirabilibus novae et veteris urbis Romae, Romae 1510, s. 75 [za: Jill Burke, Rethinking the High Renaissance. The Culture of the Visual Arts in Early Sixteenth-Century Rome, London 2012, s. 37].

18 Peter Fuhring, Hieronymus Cock and the Impact of His Published Architectural and Ornamental Prints [w:] Hieronymus Cock: The Renaissance in Print, red. Joris van Grieken, Ger Luijten, Jan van der Stock [katalog wystawy], M-Museum Leuven - Institut Néerlandais, Paris-New Haven-London 2013, s. 36-40; Anna Maria Lepacka, Pejzaż archeologiczny w grafice XVI wieku. Uwagi o narodzinach i karierze „veduta romana” [w:] Pejzaż. Narodziny gatunku 1400-1600. Materiały sesji naukowej 23-24 października 2003, red. Tadeusz J. Żuchowski, Sebastian Dudzik, Toruń 2004, s. 309.

$19 \mathrm{MNG} / \mathrm{SD} / 146 / \mathrm{ME}$, wymiary: $69 \mathrm{~cm} \times 56 \mathrm{~cm}$. 


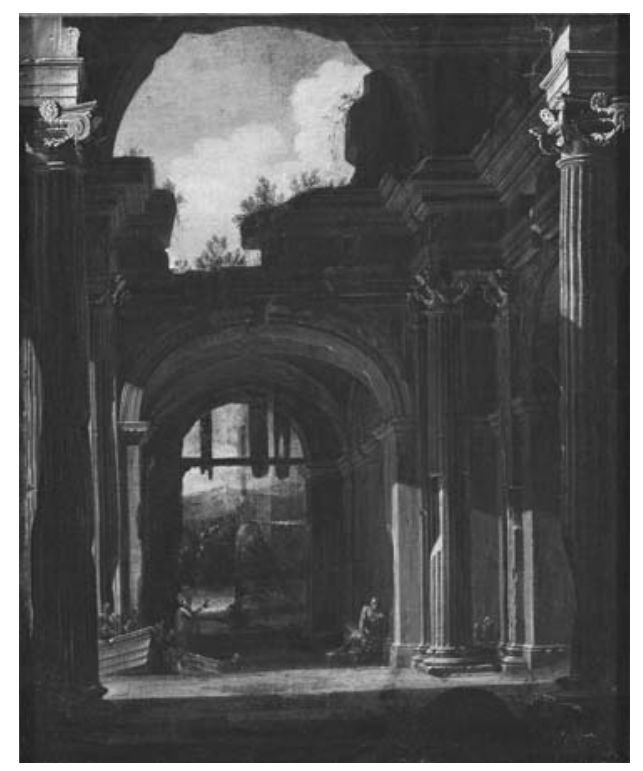

Il. 1. Viviano Codazzi [?], Capriccio architektoniczne, około 1660, olej, płótno, MNG/ SD/146/ME, Muzeum Narodowe w Gdańsku, fot. Krzysztof Sadowski

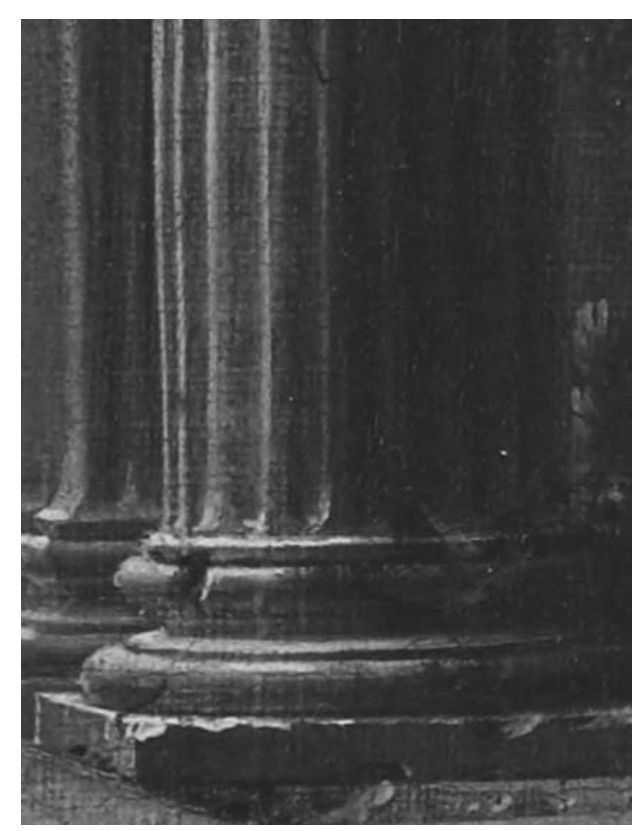

Il. 2. Viviano Codazzi [?], fragment obrazu Capriccio architektoniczne, MNG/SD/146/ME, Muzeum Narodowe w Gdańsku, fot. Krzysztof Sadowski w 1978 r., zakupiony w salonie Desa. Przedstawia on fragment zrujnowanej budowli ze sklepieniem podtrzymywanym przez cztery kolumny jońskie. W centrum kompozycji widnieje prześwit na niebo i odsunięty w głąb, lekko zamglony pejzaż z niewielkim wzniesieniem. Koloryt, dość oszczędny, określają ciepłe ugry, beże i oranże, złamane zimnym odcieniem błękitu w górnej części. Biele, delikatnie kształtujące pionowy rytm kolumnowych kanelur, zagłębień i spękań w murze, zostały naniesione impastami (il. 2). Całość tonie w ciepłym świetle zachodzącego słońca, którego promienie wpadające $\mathrm{z}$ lewej strony podkreślają przestrzenność, wszelkie wypukłości i ubytki architektonicznej bryły. Obraz budowli jest bardzo dokładny w rysunku, z precyzyjnie wykreśloną linią gzymsu i perspektywą łuku, porośniętego niezbyt bujną, symbolicznie potraktowaną roślinnością. Dwie niewielkie postaci, siedzące po przeciwnych stronach pośród monumentalnych ruin, pełnią rolę marginalnego sztafażu, potęgując wrażenie poetycznej, melancholijnej zjawiskowości.

Temat gdańskiego dzieła, zastosowane rozwiązania kompozycyjne i kolorystyczne oraz perfekcyjnie wykreślona przestrzeń kierują naszą uwagę ku twórczości Viviana Codazziego (1606-1672), związanego z Rzymem i Neapolem twórcy pejzaży architektonicznych. Artysta, urodzony w 1604 r. w Valsassina, w okolicach Bergamo, należał do czołowych przedstawicieli malarstwa architektonicznego ${ }^{20}$. W latach dwudziestych XVII w. dotarł on do Neapolu, gdzie wykazał się nabytymi już wcześniej umiejętnościami w zakresie malarstwa kwadraturowego, prawdopodobnie za sprawą współpracy

20 Więcej na temat jego życia i twórczości zob. Roberto Longhi, Viviano Codazzi e linvenzione della veduta realistica, „Paragone” 1955, t. 6, nr 71, s. 40-47; Marshall, Viviano and Niccolò Codazzi..., passim. 
z artystami z północy Włoch (zapewne z pracownią Tommasa Sandriniego, największego w owym czasie specjalisty w dziedzinie malarstwa kwadraturowego ${ }^{21}$. Niektórzy badacze sugerują jego wcześniejszy pobyt w Rzymie, brak na to jednak capriccia... dokumentów; nie widać też wyraźnych wpływów stylistycznych tamtejszego malarstwa w obrazach Codazziego ${ }^{22}$. W Neapolu artysta prawdopodobnie zetknął się z twórczością Françoisa de Nomé (1593 - po 1620), który wraz z Didierem Barrą (1590-1656) ${ }^{23}$ tworzył obrazy przedstawiające fantastyczną, monumentalną architekturę, często ulegającą destrukcji. Dzieła de Nomégo, w przeciwieństwie do Codazziego nie opierają się jednak na racjonalnym wykorzystaniu zasad perspektywy, dlatego wpływ lotaryńskiego artysty na kierunek poszukiwań Codazziego należy rozumieć ogólnie, dotyczył on raczej koncepcji i wyboru tematu.

O wiele większe znaczenie dla rozwoju przestrzennej wyobraźni artysty miały ryciny, także topograficzne, które wykorzystywane powszechnie w Neapolu, stanowiły najważniejsze źródło kompozycyjne i formalne dla wielu tamtejszych twórców. Doskonałym przykładem twórczej ich emulacji jest obraz Codazziego Adoracja Pasterzy (1638-1641, Houston, TX, The Sarah Campbell Foundation), namalowany jeszcze podczas pobytu artysty w Neapolu. Pierwowzorem dla tego dzieła była rycina Nicoletta da Modena o tym samym tytule ${ }^{24}$. Przy konstruowaniu nowych zestawień kompozycyjnych twórca posiłkował się także wzornikami architektonicznymi, zwłaszcza traktatem Jacopa Barozziego da Vignola Regola degli cinque ordini dell'architettura, wydanym w Rzymie w 1562 r. Był on dla wielu stałym źródłem wiedzy na temat porządków i podstawowych detali architektonicznych, tj. kolumn, pilastrów, belkowań.

Tym, czym sztuka Codazziego wyróżniała się na tle lokalnego malarstwa, była znajomość perspektywy i tajników quadratury. Zastosowanie tej techniki, przy jednoczesnym korzystaniu z szeroko dostępnych rycin topograficznych oraz serii graficznych obrazujących rzymskie ruiny, pozwoliło Codazziemu tworzyć - obok monumentalnych przedstawień budowli, ukazanych z topograficzną dokładnością (np. wykonana w latach trzydziestych XVII w. na podstawie miedziorytów seria czterech płócien do hiszpańskiego pałacu królewskiego Buen Retiro, obecnie w Prado) - najpowszechniejsze w jego twórczości capriccia architektoniczne. Są to wyimaginowane kompozycje, złożone z kilku form pochodzących z różnych, często powtarzalnych źródeł i nietworzące jednolitej struktury architektonicznej, ale zaaranżowane w nową całość, których celem było zaskoczenie widza ${ }^{25}$. Na ukształtowanie się nowego gatunku w twórczości Codazziego miał wpływ

21 Filippo Piazza, Rosa, famiglia [w:] Dizionario biografico degli Italiani, t. 88, Roma 2017, s. $402-405$.

22 Marshall, Viviano and Niccolò Codazzi..., s. 6-7.

23 Artyści byli znani łącznie jako Monsù Desiderio, zob. Enigma Monsù Desiderio. Un fantastique architectural au XVIIe siècle, red. Monique Sary, Maria Rosaria Nappi [katalog wystawy], Museés de la Cour d'Or de Metz, Woippy 2004.

24 Marshall, Viviano and Niccolò Codazzi..., s. 7, poz. VC 11.

25 Ibidem, s. 23. 
Alicja wyjazd z Neapolu do Rzymu po buncie Masaniella w $1647 \mathrm{r}$. Tam artysta zetknął się Andrzejewska- $\quad \mathrm{z}$ malarstwem bambocciantich. Pod ich wpływem odszedł od monumentalnych -Zajac scenografii na rzecz bardziej rodzajowych przedstawień, w których fragmenty ruin stanowily część malowniczego krajobrazu. Taki typ malarstwa twórca rozwijał do początku lat sześćdziesiątych XVII w., kiedy to ruiny w typie capriccio, zbliżone do rozwiązania z obrazu gdańskiego, zostały zastąpione architekturą pałacową ${ }^{26}$. Zamiast zniszczonych budowli z naturalistycznymi efektami kruszącej się kamieniarki pojawiły się rzędy lśniących kolumn i dekoracyjne zestawienia wielobarwnych marmurów, a zamiast melancholii - uporządkowana przestrzeń i regularność idealnej architektury.

Obraz gdański, jeśli próbować go wpisać w twórczość Codazziego, wykazuje pewne podobieństwo do dzieł powstałych w latach pięćdziesiątych i na po-

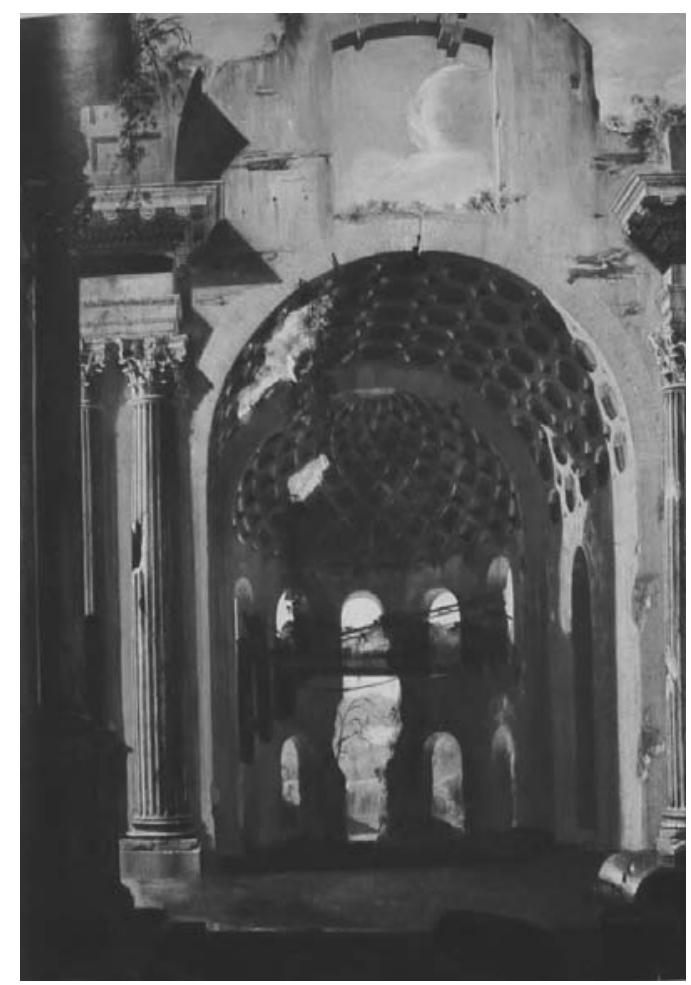

Il. 3. Viviano Codazzi, Kasetonowa absyda, 1655-1660, olej, płótno, Galleria Spada w Rzymie, repr. za: David Ryley Marshall, Viviano and Niccolò Codazzi and the Baroque Architectural Fantasy, Milano 1993, s. 201, poz. VC 90 czątku lat sześćdziesiątych XVII w. w Rzymie. Typowe dla ówczesnych dzieł artysty są piętrzące się kamienne bloki budowli, oświetlone ciepłą barwą zachodzącego słońca, którego promienie ostro przecinają kompozycję i kładą się grubymi impastami na architektonicznych detalach. Jest w gdańskim dziele właściwy artyście precyzyjny i delikatny sposób nanoszenia szczegółów, który, co trzeba podkreślić, pozostał niedościgniony dla większości naśladowców i kontynuatorów stylu włoskiego mistrza. Widoczna jest pewna organiczność form architektonicznych, spowodowana destrukcją i wykruszeniami zmurszałych murów, podporządkowana jednak nadrzędnej zasadzie kompozycyjnej. O randze artysty mogą świadczyć słowa Luigiego Lanziego: „Prawie jak Witruwiusz, precyzyjny w swojej linearnej perspektywie i dobry obserwator smaku starożytnych"27.

Porównując gdański obraz do dzieł Codazziego powstałych w latach pięćdziesiątych XVII w., takich jak Kasetonowa absyda, (1655-1660, Rzym, Galleria Spada, il. 3) ${ }^{28}$, Ruiny łuków $z$ mężczyzną,

\footnotetext{
26 Ibidem, s. 35.

27 Luigi Lanzi, Storia pittorica della Italia dal risorgimento delle belle arti fin presso al fine del XVIII secolo, t. 2, Firenze 1834, s. 178.

28 Marshall, Viviano and Niccolò Codazzi..., s. 201, poz. VC 90.
} 
kobieta i psem, (około 1655, Hanower, Niedersächsisches Landesmuseum, Landesgalerie, il. 4) $)^{29}$ czy Zrujnowane sklepienie (około 1655, kolekcja prywatna, od 1992 r. Casalmaggiore, Galeria d'Orlane, il. 5) ${ }^{30}$, nie można nie dostrzec silnych analogii w sposobie kadrowania sceny, kolorystyce i stylu malowania. Twórca gdańskiego obrazu zastosował bardzo zbliżony pomysł na oddanie faktury kamiennych bloków i kolumn, których żłobkowania, niemal reliefowo podkreślone bielą, są kształtowane ciepłym, ostrym światłem, ukośnie przecinającym kompozycję, obnażającym najdrobniejsze pęknięcia i wgłębienia zniszczonych ścian. Różowe refleksy ożywiają zacienione płaszczyzny muru. Charakterystyczne dla neapolitańskiego mistrza jest także dość częste aranżowanie kompozycji w ten sposób, iż jej centralnym punktem jest rozświetlony otwór w murze, za którym dostrzegamy delikatnie kształtowany, przejrzysty pejzaż; pojawiają się też zacienienie pierwszego planu i drobne postaci, jakby

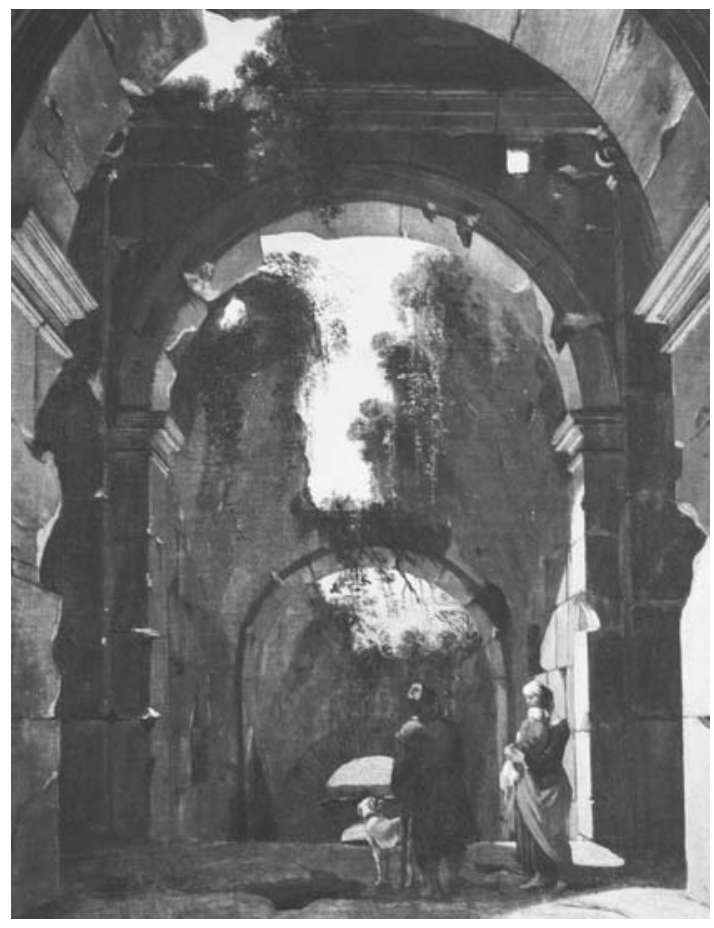

Il. 4. Viviano Codazzi, Ruiny łuków z mężczyzną, kobieta i psem, około 1655, olej, płótno, Niedersächsische Landesgalerie w Hanowerze, repr. za: David Ryley Marshall, Viviano and Niccolò Codazzi and the Baroque Architectural Fantasy, Milano 1993, s. 193, poz. VC 82 przytłoczone monumentalną architekturą. W obrazie Zrujnowane kolumny na Forum Nerwy (1663, Museo Nazionale d'Arte Medievale e Moderna w Arezzo, il. 6) zastosowano szczególnie silne efekty światłocieniowe, wydobywające załamania i wypukłości rzeźbiarskich detali oraz pęknięć w murze, co widoczne jest także w dziele gdańskim.

Obraz z Muzeum Narodowego w Gdańsku, podobnie jak inne prace Codazziego, wykazuje czytelne odniesienia do graficznego wzorca przedstawiającego widok ruin term Dioklecjana, ryciny będącej częścią wspomnianej już popularnej serii ilustracji zamieszczonych w Discorso sopra le antichità di Roma Vincenza Scamozziego, publikacji wydanej w Wenecji przez Girolamo Porro w $1582 \mathrm{r}^{31}$ (il. 7). Artysta wykorzystał graficzny motyw do stworzenia rozbudowanej, wyimaginowanej wizji, łączącej pozostałości struktur architektury starożytnej z budowlami nowożytnymi. Joński porządek kolumn i pilastra,

29 Ibidem, s. 193, poz. VC 82.

$30 \quad$ Ibidem, s. 281, poz. VC 158.

31 Vincenzo Scamozzi, Discorso sopra le antichità di Roma, Venezia 1582, tabl. 31, 32. 


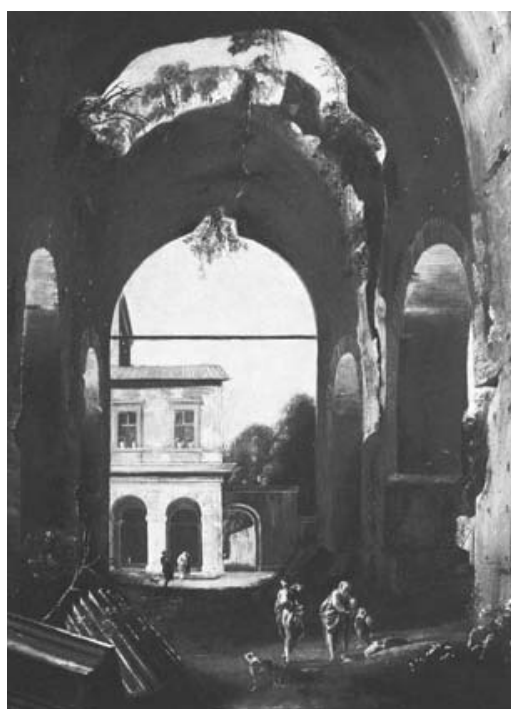

Il. 5. Viviano Codazzi, Zrujnowane sklepienie, około 1655, olej, płótno, kolekcja prywatna, Galleria d'Orlane w Casalmaggiore, repr. za: David Ryley Marshall, Viviano and Niccolò Codazzi and the Baroque Architectural Fantasy, Milano 1993, s. 281, poz. VC 158

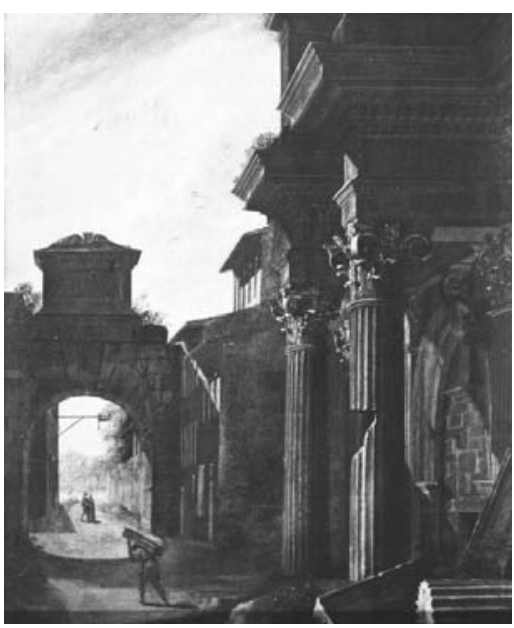

Il. 6. Viviano Codazzi, Zrujnowane kolumny na Forum Nerwy, 1663, olej, płótno, Museo Nazionale d’Arte Medievale e Moderna w Arezzo, fot. Museo Nazionale d'Arte Medievale e Moderna w Arezzo wzbogacony girlandami, zbliżony jest do kapiteli z Palazzo dei Conservatori w Rzymie, zrealizowanych według projektu Michała Anioła ${ }^{32}$ (il. 8). Bliskie schematowi zastosowanemu przez autora obrazu gdańskiego są także kapitele podwójnych kolumn jońskich, zdobiące klasycyzującą fasadę kościoła Santa Maria della Sapienza w Neapolu, którego architektem był Cosimo Fanzago (1591-1678). Jest to tym bardziej istotne, że Fanzago był nauczycielem i współpracownikiem Codazziego w okresie neapolitańskim, a poza pracą łączyły ich bliskie relacje ${ }^{33}$.

Tropem Codazziego podążało wielu artystów, malując dzieła często powierzchownie naśladujące osiągnięcia mistrza. Ascanio Luciano, utożsamiany $\mathrm{z}$ „pseudo-Codazzim”" ${ }^{4}$, do twórczości mistrza odwoływał się zwłaszcza we wczesnym okresie działalności i były to głównie odniesienia do neapolitańskiego okresu artysty, lat czterdziestych XVII w. - dzieła przedstawiające monumentalne portyki, pałacowe kolumnady, skomplikowane struktury architektoniczne, które Luciano nie zawsze rozumiał w sposób prawidłowy, czyniąc je nieprzejrzystymi i niekonsekwentnie rozkładając światłocień ${ }^{35}$. Dzieła pochodzącego z Walencji Vicenta Ginera, specjalizującego się w malowaniu rozbudowanych kompozycji architektonicznych, wieloczłonowych układów fantazyjnie piętrzących się kondygnacji animowanych przez liczne postacie, także wskazują na wpływ neapolitańczyka $^{36}$. Bliskie na pozór rozwiązaniom mistrza,

32 W traktacie architektonicznym z $1615 \mathrm{r}$. Vincenzo Scamozzi po raz pierwszy opublikował, wraz z obszernym komentarzem, ilustrację jońsko-diagonalnego kapitelu $\mathrm{z}$ narożnymi wolutami $\mathrm{w}$ typie widocznym na obrazach Viviana i Niccolò Codazzich, zob. Vincenzo Scamozzi, L'idea della architettura universale, Venezia 1615, s. 85-101.

33 Marshall, Viviano and Niccolò Codazzi..., s. 13

34 David R. Marshall, Ascanio Luciano, a Neapolitan follower of Viviano Codazzi, „Paragone” 1988, t. 39, nr 455, s. 21-43.

35 Marshall, Viviano and Niccolò Codazzi..., s. 437-439.

36 Pomimo braku przesłanek archiwalnych badacze wskazują na Ginera jako autora postaci na obrazach Codazziego, 


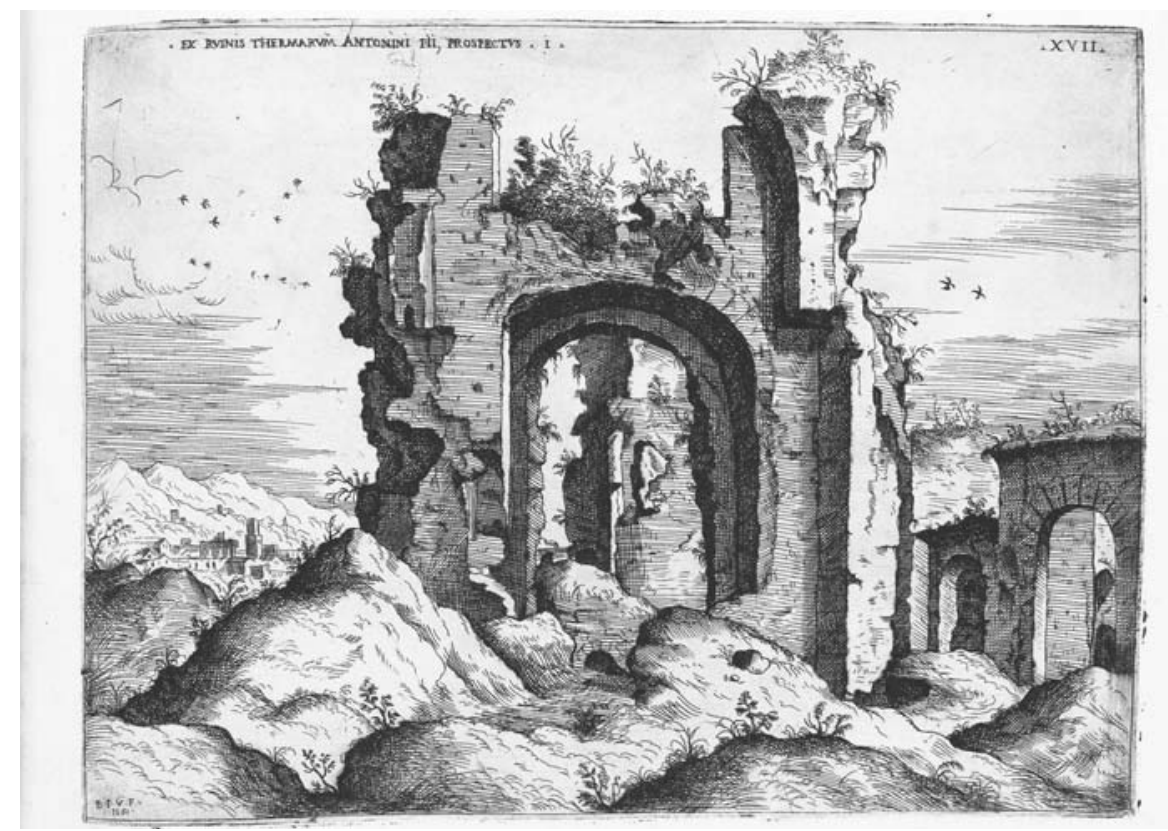

Dwa

capriccia...

Il. 7. Giovanni Battista Pittoni, tablica nr 32, w: Vincenzo Scamozzi, Discorso sopra le antichità di Roma, Venetia, 1582, akwaforta, Herzog August Bibliothek Wolfenbüttel: A: 3.3 Geom. (1)

głównie z wczesnych lat sześćdziesiątych XVII w., są jednak wykonane w sposób mniej wyrafinowany, bardziej sztywny i pozbawiony swobody pędzla. Czy zatem gdańskie capriccio jest dziełem Viviana Codazziego? Spośród obrazów naśladujących twórczość neapolitańskiego artysty malowidło z Muzeum Narodowego w Gdańsku wyróżnia doskonała znajomość perspektywy, głębokie zrozumienie architektury, precyzja rysunku i wyjątkowa wrażliwość na niuanse światłocieniowe. Bardzo podobny repertuar form, zbliżony do widocznych na gdańskim obrazie, można odnaleźć wprawdzie u syna artysty, Niccola Codazziego, którego dzieła z lat sześćdziesiątych i siedemdziesiątych XVII w. są wersjami bądź kopiami prac ojca ${ }^{37}$. W porównaniu z twórczością Viviana, Niccolò porzucił jednak dbałość o naturalistyczne efekty, podkreślając malowniczość detali kosztem spójności struktury architektonicznej. Używając plastycznego języka ojca, nieco inaczej aranżował światło w obrazie - tak, by uwypuklić teatralność malowanej sceny; był także mniej dokładny w tworzeniu perspektywicznego rysunku ${ }^{38}$. Dość trudne do uchwycenia różnice sprawiają, że dzieła Codazzich bywają obecnie często mylone.

zob. Marshall, Viviano and Niccolò Codazzi..., s. 512-513; Ángel Aterido Fernández, De Castellón a Roma: el canónigo Vicente Giner (ca. 1636-1681), „Archivo Español de Arte” 2001, t. 294, s. 183.

37 Marshall, Viviano and Niccolò Codazzi..., s. 53; idem, The Roman Baths Theme..., s. $133-159$.

38 Ibidem, s. 140-142. 


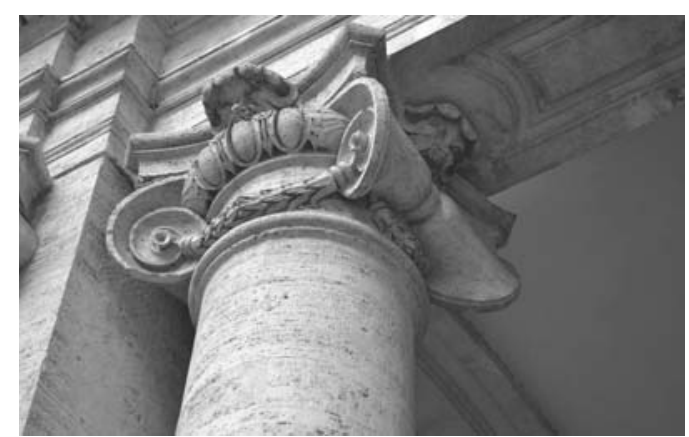

Il. 8. Kapitel kolumny, Palazzo dei Conservatori w Rzymie, fot. Alicja Andrzejewska-Zając

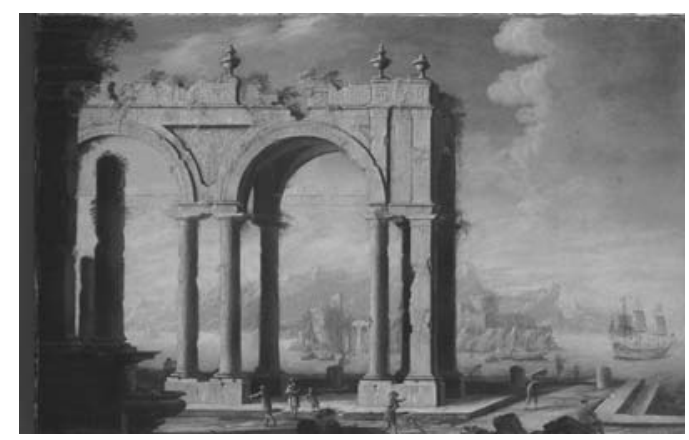

Il. 9. Gennaro Greco [?], Capriccio architektoniczne, pierwsza poł. XVIII w., olej, płótno, MNG/SD/48/ ME, Muzeum Narodowe w Gdańsku, fot. Grzegorz Nosorowski
Niestety, jednoznaczną identyfikację autora gdańskiego capriccio utrudnia stan zachowania obrazu. Zanim znalazł się on w muzeum, uległ znacznemu zniszczeniu na skutek niewłaściwych warunków przechowywania bądź niefortunnej konserwacji: partie architektoniczne i postaci w tle zostały częściowo przemyte. Być może zdjęcie zabrudzonego werniksu odsłoniłoby wszystkie walory dzieła, które pomimo uszkodzeń należy do wyjątkowych w muzealnej kolekcji, a jego wciąż czytelna wysoka klasa artystyczna wskazuje na bliskie związki z malarstwem samego Codazziego.

Więcej szczęścia miał drugi obraz ${ }^{39}$ (il. 9), który, podobnie jak omawiany powyżej, znalazł się w gdańskim Muzeum Narodowym po drugiej wojnie światowej jako jeden $\mathrm{z}$ wielu zabytków przekazanych ze składnicy konserwatorskiej. Uchodził za dzieło nieznanego malarza. Rozległe zniszczenia, zdeformowanie powierzchni płótna, liczne, wcześniejsze przemalowania i pociemniały werniks utrudniały jego odbiór i skazywały na magazynowy niebyt. Dzięki doskonałej konserwacji przeprowadzonej w ostatnich latach obraz odzyskał swój pierwotny świetlisty koloryt i należytą rangę w muzealnej kolekcji ${ }^{40}$.

Malowidło przedstawia widok portu z ruinami wyimaginowanej, pałacowej architektury w formie dwóch arkad, ustawionych po lewej stronie na wykreślonym perspektywicznie kamiennym podeście schodzącym ku wodzie. Twórca przeciwstawił dość ciemny pierwszy plan jasnemu tłu, ukazującemu w rozproszonym, chłodnym świetle wody morskiej zatoki. Na obrazie można dostrzec delikatny, malowany subtelnymi pociągnięciami pędzla, zarys wyspy z zabudowaniami, żaglowce i piętrzący się górski masyw, obwiedziony złocistą poświatą. Na pierwszym planie, pośród fragmentów zrujnowanych budowli, ukazano niewielkie postacie, zajęte codziennymi czynnościami. Ich stroje stanowią jedyny żywy akcent kolorystyczny kompozycji. Obraz namalowano swobodnie i z dużą

39 MNG/SD/48/ME, wymiary: $49 \mathrm{~cm} \times 75 \mathrm{~cm}$.

40 Konserwację przeprowadziła Małgorzata Wojewódzka z Pracowni Konserwacji Muzeum Narodowego w Gdańsku. 
wprawą, za pomocą ograniczonej palety, z której wydobyto bogactwo tonalne o szerokiej gamie błękitów i szarości. Kompozycja gdańskiego dzieła z ukazanym fragmentem monumentalnej pałacowej ruiny na nabrzeżu oraz zaprezentowane w tle efekty luministyczne wskazują na pracę neapolitańskiego malarza, Gennara Greca (1663-1714).

W 1743 r. autor pierwszej biografii Greca, Bernardo de’Dominici, pisał: „Gennaro malował różnorodną, zrujnowaną architekturę i inne wspaniałe konstrukcje, ukazywał wyimaginowane więzienia o okropnym wyglądzie" ${ }^{41}$. Niezwykłe walory malarskie i luministyczne dzieł Greca oraz tematyka jego dekoracyjnych przedstawień zapewniły artyście - według słów biografa - dostatek i sławę za życia ${ }^{42}$. Artysta znany był pod pseudonimem Mascacotta (w dosłownym tłumaczeniu - ugotowana twarz) z powodu rozległego oparzenia, którego doznał w dzieciństwie i które zniekształciło mu twarz. Nie przeszkodziło mu to jednak w zawarciu trzech małżeństw i posiadaniu wielu synów, z których przeżył tylko jeden, Vincenzo - on także zajmował się malarstwem ${ }^{43}$. Pierwsze nauki artysta pobierał w lokalnym warsztacie, ucząc się malarstwa kwadraturowego. Początkowo pracował jako malarz dekoracyjny. Z pewnością zgłębiał także traktat Andrei del Pozzo Perspectiva pictorum et architectorum, który - wydany w Rzymie w 1693 r. - systematyzował wiedzę na temat perspektywy i sumował ustalenia szesnasto- i siedemnastowiecznych teoretyków. Następnie Greco, jako specjalista od perspektywy, rozpoczął współpracę z czołowymi neapolitańskimi malarzami późnobarokowymi: Paolem de Matteis i Franceskiem Solimeną. Zajmował się także tworzeniem obrazów sztalugowych przedstawiających kompozycje architektoniczne i wyimaginowane widoki. Greco zginął w 1714 r. w wyniku niefortunnego upadku podczas malowania fresków w kościele w Noli, w okolicach Neapolu ${ }^{44}$.

W 1954 r. Oreste Ferrari opublikował artykuł, w którym prezentował badania nad środowiskiem neapolitańskich malarzy architektonicznych XVIII w. Czerpiąc $\mathrm{z}$ dostępnych źródeł i epizodycznych opracowań z początku XX w. ${ }^{45}$, usystematyzował on stan badań i nakreślił sylwetki najważniejszych artystów, wyróżniając twórczość Leonarda Coccorante. Zespoły baśniowych ruin, wyimaginowanych pałaców, piętrzących się kolumnad i portyków schodzących ku morskiemu brzegowi były, według Ferrariego, wynikiem tradycji obrazowej, zaszczepionej w Neapolu na początku XVII w. przez przybyłego z Lotaryngii Françoisa de Nomé oraz

41 Bernardo de’Dominici, Vite de' pittori, scultori ed architetti napoletani, t. 3, Napoli 1743, s. 555.

42 Ibidem, s. 553-555.

43 Twórczość Vincenza Greca nie jest wystarczająco zbadana. Znane są cztery sygnowane dzieła artysty, ujawniające wyraźne wpływy Leonarda Coccorante, obecnie w Národní Galerie w Pradze, zob. Gennaro Borrelli, Il rococò napoletano, „Napoli nobilissima: rivista di topografia ed arte napoletana" 1979, t. 18, s. 219.

44 de'Dominici, Vite de' pittori..., s. 555; Hermann Voss, Panninesque Paintings before Pannini, „Apollo” 1926, t. 3, s. 333-335; Ulisse Prota-Giurleo, Pittori Napoletani del Seicento, Napoli 1953, s. 88.

45 Voss, Panninesque Paintings..., s. 332-336. 
Alicja przez „Witruwiusza perspektywy” - Codazziego ${ }^{46}$. Wpływ tego ostatniego artysty Andrzejewska- na kształt malarstwa Greca jest zauważalny zwłaszcza w zamiłowaniu do silnych -Zając kontrastów światłocieniowych i rytmicznych powtórzeń detali architektonicznych, takich jak arkady, kolumny, balustrady, posągi czy obeliski. Greco nawet nie próbowal - w przeciwieństwie do siedemnastowiecznego mistrza - nadać swoim dziełom rysu wiarygodności, podkreślał raczej ich fantazyjność i nierealność. Malowana architektura stała się efektowną atrapą i swobodną wariacją na temat bogato dekorowanych starożytnych pozostałości. Jak zauważył Ferrari, dawała odczucie „bezkresnej melancholijnej wielkości, kontrastującej z codzienną swobodą sceny figuralnej”47. Artysta tworzył „fałszywy teatr na wolnym powietrzu”48. O związkach malarstwa neapolitańskiego z teatrem w XVIII w. świadczy fakt, że wielu tamtejszych malarzy było zaangażowanych w tworzenie scenografii, jak choćby Giuseppe Capelli, który według doniesień de’Dominiciego rywalizował z Grekiem „w perspektywach”, czy syn Giuseppa - Pietro (1700-1727) ${ }^{49}$.

Kompozycja gdańskiego dzieła jest analogiczna do rozwiązania zastosowanego przez Greca w dwóch obrazach znajdujących się w Museé des Beaux-Arts w Besançon ${ }^{50}$ (il. 10, 11). Pierwszoplanowa ruina, $\mathrm{w}$ formie powtarzających się arkad i kolumn, z subtelnie i drobiazgowo naniesionymi detalami, została skupiona we wszystkich trzech dziełach po jednej ze stron kompozycji. Można dostrzec także ten sam kamienny brzeg i wykreślony perspektywicznie stylobat, drobiazgowo malowane żaglowce oraz podobny sposób traktowania światła, które lekko kształtuje masy budowli, nadając im miejscami odcień jasnej ochry. Widoczne jest podobieństwo w malowaniu srebrzysto-błękitnego pejzażu, stanowiącego tło dla światłocieniowej sceny na pierwszym planie. Przy dolnej krawędzi autor wszystkich trzech płócien umieścił w cieniu charakterystyczne źdźbła traw i łodygi oraz rozrzucone monumentalne pozostałości zrujnowanej budowli, tworzące swoiste obramienie dla rozświetlonego centrum kompozycji. Bardzo podobne rozwiązania, przemawiające za proponowaną atrybucją, znajdujemy również w dziełach, które pojawiły się w ostatnich latach na rynku antykwarycznym w Gloucester (Chorley’s, 21.11.2018) ${ }^{51}$ i w Paryżu (Artcurial, 19.11.2014, il. 12) $)^{52}$. Inne porównywalne prace Greca są licznie reprezentowane

46 Oreste Ferrari, Leonardo Coccorante e la „veduta ideata” napoletana, „Emporium” 1954, t. 119, s. 9.

47 Ibidem, s. 15.

48 Nicola Spinosa, Pittura napoletana del Settecento. Dal barocco al rococò, t. 1, Napoli 1986, s. 76.

49 Katarzyna Murawska-Muthesius, Il teatro neapoletano delle rovine: i quadri della cerchia di Leonardo Coccorante e di Gennaro Greco nelle raccolte polacche, „Bulletin du Musée National de Varsovie" 1998, t. 39, s. 87.

50 Arnauld Brejon de Lavergnée, Peintures napolitaines du Musée des Beaux-Arts et d'Archéologie de Besançon [katalog wystawy], Museé d'Unterlinden, Colmar 1986, s. 40-41.

${ }_{51} \mathrm{http} / /$ www.chorleys.com/Catalogues/ourcatalogues.aspxCatalogue $=126 \&$ Section $=2600$ \&Lot=109034\&pg=lot\# [dostęp 15.09.2019].

52 https://www.artcurial.com/en/lot-gennaro-greco-naples-1663-1714-temples-antiques-sur-un-littoral-mediterraneen-anime-de [dostęp: 15.09.2019]. 


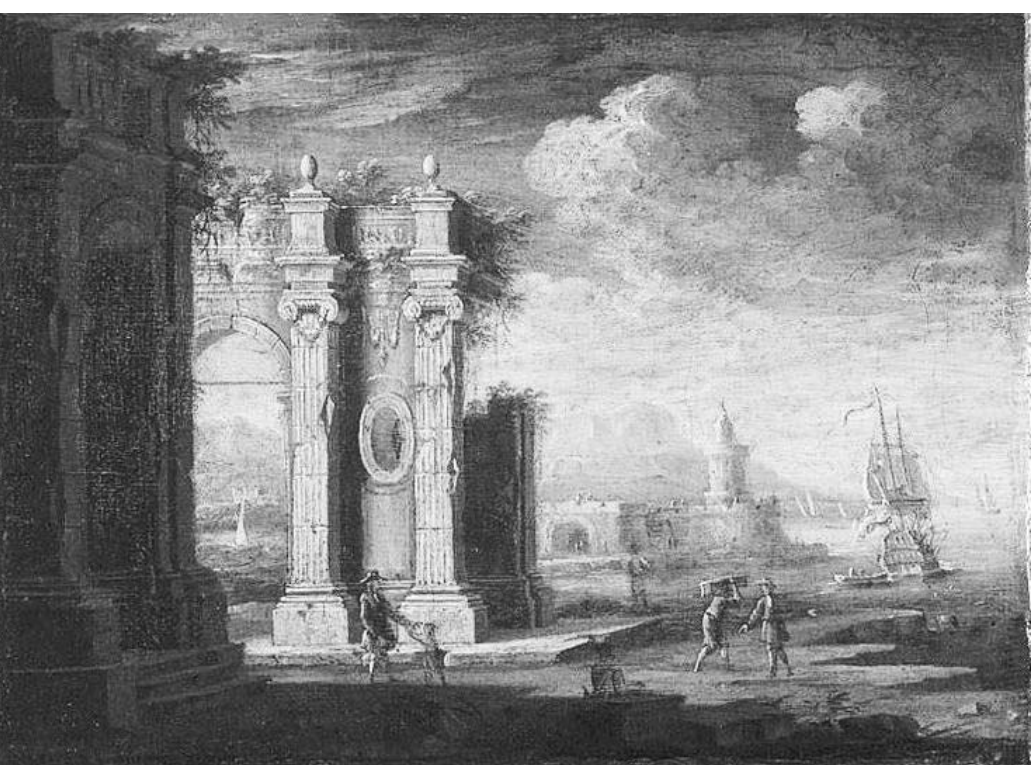

Il. 10. Gennaro Greco (atr.), Capriccio architektoniczne (1), pierwsza poł. XVIII w., Musée des Beaux-Arts et d'Archéologie w Besançon, fot. P. Guenat, inv. 897.1.41

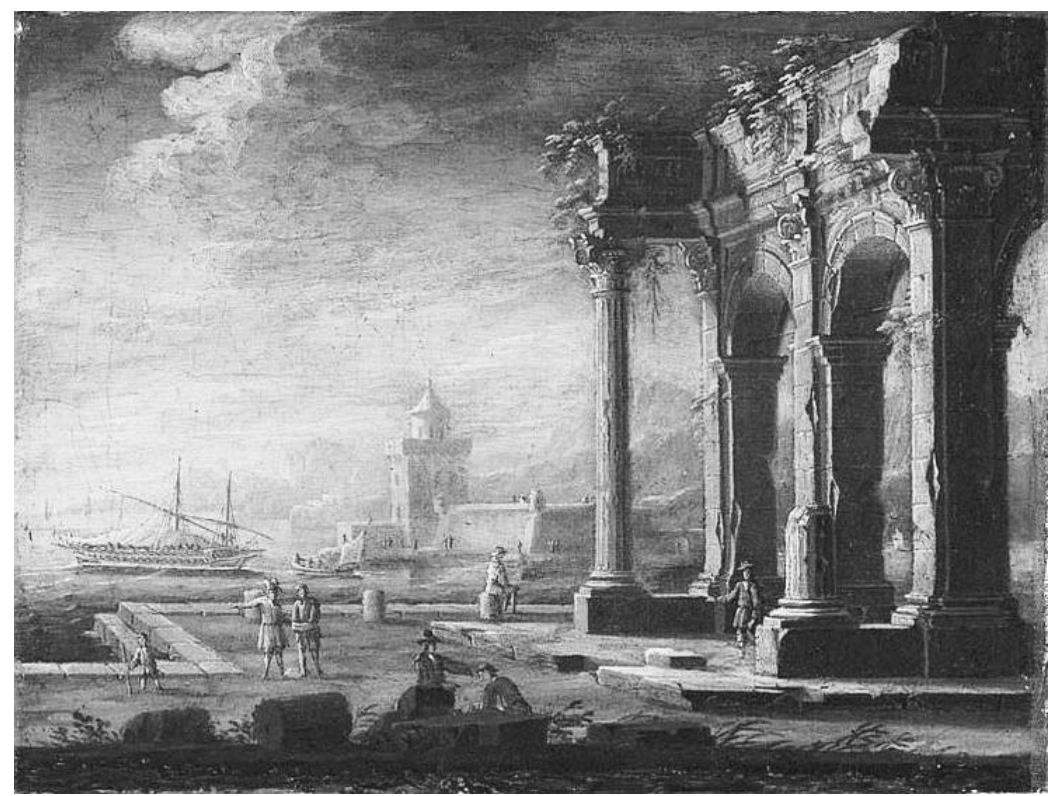

Il. 11. Gennaro Greco (atr.), Capriccio architektoniczne (2), pierwsza poł. XVIII w., Musée des Beaux-Arts et d'Archéologie w Besançon, fot. P. Guenat, inv. 897.1.42 


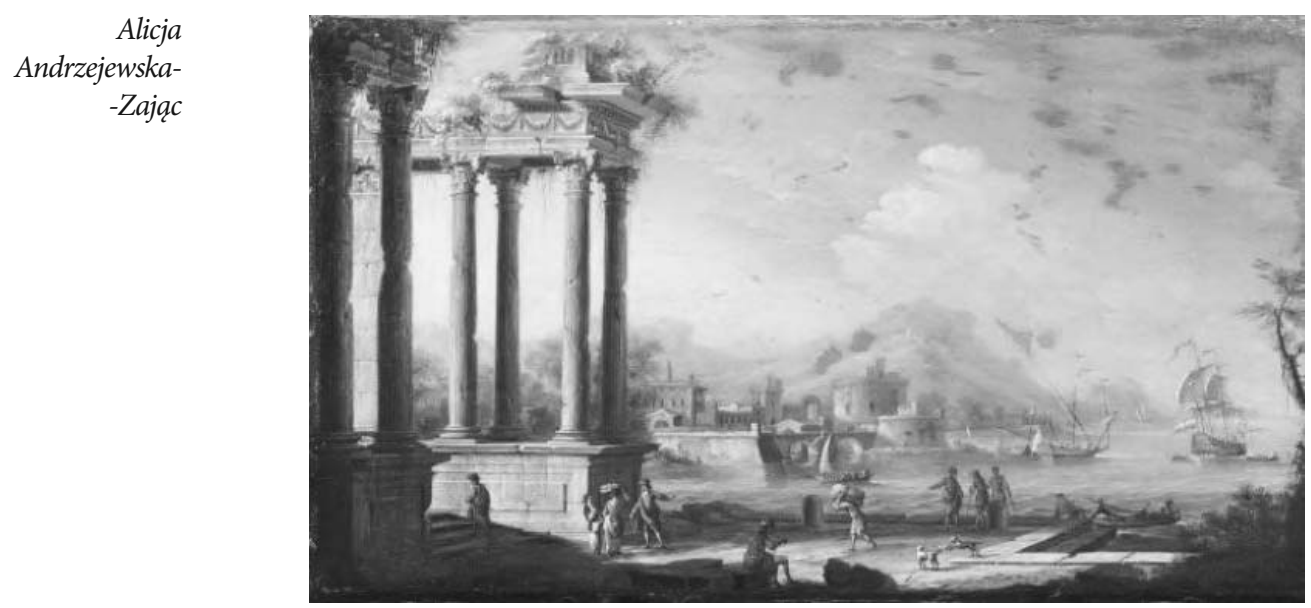

Il. 12. Gennaro Greco, Capriccio architektoniczne, pierwsza poł. XVIII w., Artcurial, Paryż, fot. @ Artcurial

w światowych zbiorach, m.in. w kolekcji Molinari Pradelli w Castenaso ${ }^{53}$, w Snite Museum of Art w Notre-Dame w Indianie ${ }^{54}$, w Musée de Bastia na Korsyce ${ }^{55}$ i Musée des Beaux-Arts w Rouen (dwie sygnowane prace) ${ }^{56}$. W obliczu braku podpisu na gdańskim obrazie trudno jednak z całkowitą pewnością przypisać jego autorstwo neapolitańskiemu twórcy.

Problemem pozostaje także duża liczba malowideł naśladujących tematycznie i formalnie modny w pierwszej połowie XVIII w. styl Greca, takich jak dzieła Angela Marii Costy, artysty urodzonego w Palermo, którego twórczość jest na tyle mało znana, że trudno przypisywać mu bez cienia wątpliwości jakiekolwiek dzieła ${ }^{57}$, czy obrazy wspomnianego już ucznia Costy, Leonarda Coccorante $^{58}$. Dzieła tego ostatniego - nadmorskie widoki fantazyjnych, niepokojących ruin - były malowane ze znacznie większą ekspresją i silniejszym dramatyzmem, podkreślonym ostrymi kontrastami światłocieniowymi, stając się często pretekstem do ukazania niezwykłych zjawisk atmosferycznych (m.in. capriccia

53 Carlo Volpe, La raccolta Molinari Pradelli. Dipinti del Sei-e Settecento, Firenze 1984, s. 143.

54 Federico Zeri, Census of pre-nineteenth century Italian paintings in North American public collections, Cambridge 1972, s. 95.

55 Benjamin Couilleaux, Marylène Dinelli-Graziani, Elisabeth Cornetto, Ariane Jurquet, Peintures Napolitaines, Fragments de la collection Fesch, Bastia 2012, s. 120.

56 Olga Popovitch, Catalogue des peintures du Musée des beaux arts de Rouen, Rouen 1978, s. 63.

57 Giancarlo Sestieri, Il Capriccio architettonico in Italia nel XVII e XVIII secondo, t. 1, Roma 2015, s. 382-383.

58 Gennaro Borrelli, Leonardo Coccorante o del realismo magico, „Realtà del mezzogiorno: mensile di politica, economica e cultura" 1974, t. 14, nr 12, s. 957-972; Spinosa, Pittura napoletana..., s. 69-75, 89, 173-174, 344-350; Rossana Muzii, Leonardo Coccorante [w:] La pittura di paesaggio in Italia. Il Settecento, red. Anna Ottani Cavina, Emilia Calbi, Milano 2005, s. $158-160$. 
architektoniczne w Musée de Grenoble $e^{59}$, The Walters Art Gallery ${ }^{60}$ i National Gallery w Dublinie $\left.{ }^{61}\right)$.

Aby umożliwić jednoznaczną weryfikację podjętej tu próby atrybucji, oba omówione obrazy włoskie z kolekcji Muzeum Narodowego w Gdańsku winny być ponownie przeanalizowane po uważnej restauracji pierwszego z nich i w kontekście rozszerzonego materiału porównawczego.

\section{Bibliografia}

Albertini Francesco, Opusculum de mirabilibus novae et veteris urbis Romae, Romae 1510.

Białostocki Jan, Narodziny nowożytnego krajobrazu [w:] Narodziny krajobrazu nowożytnego. Katalog wystawy ze zbiorów Ermitażu, Drezna, Pragi, Budapesztu oraz muzeów polskich [katalog wystawy], Muzeum Narodowe w Warszawie, Warszawa 1972.

Borrelli Gennaro, Il rococò napoletano, „Napoli nobilissima: rivista di topografia ed arte napoletana" 1979 , t. 18, s. 219.

Borrelli Gennaro, Leonardo Coccorante o del realismo magico, „Realtà del mezzogiorno: mensile di politica, economica e cultura" 1974, t. 14, nr 12, s. 957- 972.

Brejon de Lavergnée Arnauld, Peintures napolitaines du Musée des Beaux-Arts et d'Archéologie de Besançon [katalog wystawy], Museé d'Unterlinden, Colmar 1986.

Burke Jill, Rethinking the High Renaissance. The Culture of the Visual Arts in Early Sixteenth-Century Rome, London 2012.

Cavazzini Patrizia, Painting as Business in Early Seventeenth-Century Rome, Pennsylvania 2008.

Chiarini Marco, Tableaux italiens: Catalogue raisonné de la collection de peinture italienne XIVe-XIXe siècles: Grenoble, Musée de peinture et de sculpture, Grenoble 1988.

Couilleaux Benjamin, Dinelli-Graziani Marylène, Cornetto Elisabeth, Jurquet Ariane, Peintures Napolitaines, Fragments de la collection Fesch, Bastia 2012.

Crispolti Enrico, Enciclopedia Universale dell' Arte, Venezia-Roma 1958.

Das Capriccio als Kunstprinzip. Zur Vorgeschichte der Moderne von Arcimboldo und Callot bis Tiepolo und Goya, red. Ekkehard Mai, Joachim Rees [katalog wystawy], Kunsthistorisches Museum Wien, Wien 1996.

de'Dominici Bernardo, Vite de' pittori, scultori ed architetti napoletani, t. 3, Napoli 1743.

DiFuria Arthur J., Maarten van Heemskerck's Rome. Antiquity, Memory, and the Cult of Ruins, Leiden-Boston 2018

59 Ferrari, Leonardo Coccorante..., s. 11; Marco Chiarini, Tableaux italiens: Catalogue raisonné de la collection de peinture italienne XIVe-XIXe siècles: Grenoble, Musée de peinture et de sculpture, Grenoble 1988, s. 46.

60 https://art.thewalters.org/detail/29701/stormy-seacoast-with-classical-ruins/ [dostęp: 15.09.2019].

${ }_{61} \mathrm{http}: / /$ catalogo.fondazionezeri.unibo.it/scheda.v2.jsp?tipo_scheda=F\&id=118327\&titolo $=$ National $\% 20$ Gallery\%20of\%20Ireland $\% A 0 \% 20 \% A 0$ Coccorante $\% 20$ Leonardo\%20(?)\%20-\%20 sec.\%20XVIII\%20-\%20Tempesta\%20marina\&locale=it\&decorator=layout_resp\&apply=true [dostęp: 15.09.2019]. 
Alicja Enigma Monsù Desiderio. Un fantastique architectural au XVII siècle, red. Monique AndrzejewskaSary, Maria Rosaria Nappi [katalog wystawy], Museés de la Cour d'Or de Metz, Woippy 2004.

Fernández Ángel Aterido, De Castellón a Roma: el canónigo Vicente Giner (ca. 1636-1681), „Archivo Español de Arte” 2001, t. 294, s. 179-183.

Ferrari Oreste, Leonardo Coccorante e la „veduta ideata” napoletana, „Emporium” 1954, t. 119, s. 9-20.

Fuhring Peter, Hieronimus Cock and the Impact of His Published Architectural and Ornamental Prints [w:] Hieronymus Cock: The Renaissance in Print, red. Joris van Grieken, Ger Luijten, Jan van der Stock [katalog wystawy], M-Museum Leuven- Institut Néerlandais Paris, New Haven-London 2013.

Hartmann Lucrezia, Capriccio. Bild und Begriff, Nürnberg 1973.

Hülsen Christian, Hermann Egger, Die Römischen Skizzenbücher von Maarten van Heemskerck im Königlichen Kupferstichkabinett zu Berlin, Bd. 1-2, Berlin 1913-1916.

Lanzi Luigi, Storia pittorica della Italia dal Risorgimento delle belle arti fin presso al fine del XVIII secolo, t. 2, Firenze 1834.

Lepacka Anna Maria, Pejzaż archeologiczny w grafice XVI wieku. Uwagi o narodzinach $i$ karierze „veduta romana” [w:] Pejzaż. Narodziny gatunku 1400-1600. Materiały sesji naukowej, 23-24 października 2003, red. Tadeusz J. Żuchowski, Sebastian Dudzik, Toruń 2004, s. 305-318.

Longhi Roberto, Viviano Codazzi e l'invenzione della veduta realistica, „Paragone” 1955 , t. 6, nr 71, s. 40-47.

Marshall David R., Ascanio Luciani, a Neapolitan follower of Viviano Codazzi, „Paragone” 1988, t. 39, nr 455, s. 21-43.

Marshall David Ryley, The Roman Baths Theme from Viviano Codazzi to G.P. Pannini: transmission and transformation, „Artibus Et Historiae” 1991, t. 12, nr 23, s. 129-159.

Marshall David Ryley, Viviano and Niccolò Codazzi and the Baroque Architectural Fantasy, Milano 1993.

Murawska-Muthesius Katarzyna, Il teatro neapoletano delle rovine: i quadri della cerchia di Leonardo Coccorante e di Gennaro Greco nelle raccolte polacche, „Bulletin du Musée National de Varsovie" 1998, t. 39, s. 71-89.

Muzii Rossana, Leonardo Coccorante [w:] La pittura di paesaggio in Italia. Il Settecento, red. Anna Ottani Cavina, Emilia Calbi, Milano 2005.

Piazza Filippo, Rosa, famiglia [w:] Dizionario biografico degli Italiani, t. 87, Roma 2017, s. 402-405.

Popovitch Olga, Catalogue Des Peintures Du Musée Des Beaux Arts De Rouen, Rouen 1978.

Prota-Giurleo Ulisse, Pittori Napoletani del Seicento, Napoli 1953.

Rathé Alice, Le capriccio dans les écrits de Vasari, „Italica. Journal of the American Association of Teachers of Italian" 1980, t. 57, nr 4, s. 239-254.

Ripa Cesare, Ikonologia, przeł. Ireneusz Kania, Kraków 2004.

Scamozzi Vincenzo, Discorso sopra le antichità di Roma, Venezia 1582.

Scamozzi Vincenzo, L’idea della architettura universale, Parte 2, Libro 6, Cap. 21, Venezia 1615.

Sestieri Giancarlo, Il Capriccio architettonico in Italia nel XVII e XVIII secondo, t. 1, Roma 2015.

Spinosa Nicola, Pittura napoletana del Settecento. Dal barocco al rococò, t. 1, Napoli 1986. 
Volpe Carlo, La raccolta Molinari Pradelli. Dipinti del Sei- e Settecento, Firenze 1984. Voss Hermann, Panninesque Paintings before Pannini, „Apollo” 1926 t. 3, s. 393-335. Zeri Federico, Census of pre-nineteenth century Italian paintings in North American public collections, Cambridge 1972.

Zeri Federico, La nascità della battaglia come genere e il ruolo del Cavalier d'Arpino [w: La battaglia nella pittura del XVII e XVIII secolo, red. Patrizia Consigli Valenti, Parma 1986, s. 9-27.

\section{Two Architectural Caprices from the Collection of the National Museum in Gdańsk - an Attempt at Attribution}

The article analyses two Italian paintings from the collection of the National Museum in Gdańsk, which so far have not been a subject of scientific inquiry. Both works, of unknown provenance and authorship, were included in the Museum's collection after World War II. They are architectural capriccios: a type of landscape in which buildings or their fragments, often supplemented by staffage, are placed in juxtaposition with fantastical objects produced by artistic imagination. The popularity of these architectural pieces and their development as an independent genre can be observed from the first half of the $17^{\text {th }}$ century, and it is paintings by Viviano Codazzi (1606-1672) and Alessandro Salucci (1590-1655) that were instrumental in the appearance of the fashion for such motifs.

Based on the comparative stylistic analysis, an attempt was made to attribute the works from the Gdańsk collection to the two leading Neapolitan artists from the $17^{\text {th }}$ and $18^{\text {th }}$ century. The first painting shows a clear dependence on the work of the already mentioned Viviano Codazzi, an artist associated with Naples and Rome. The painting displays similarities to the artist's works from the 1650s and the 1660 s with the characteristic solutions in the field of composition and chiaroscuro. We can see the same precise way of applying architectural details and the perfect knowledge of the principles of perspective, unsurpassed by any of his numerous followers. The second painting, showing the view of a port with picturesque ruins in the foreground, was assigned to Gennaro Greco (1663-1714), a creator of imaginary architectural landscapes and the master of luminist effects and sublime, delicate colour. This pioneering artist, working at the turn of the $18^{\text {th }}$ century was considered the most important Neapolitan painter of his time.

Despite the large number of works presenting architectural capriccios which have survived in public and private collections, this painting genre remains one of the most difficult to study. This results from the fact that capriccios were usually not painted by top-class artists, and many paintings remain anonymous. The two paintings from Gdańsk museum's collection stand out due to their stylistic features characteristic of the greatest creators of this painting genre.
Dwa

capriccia... 